\title{
Corpos tatuados: Uma expressão identitária do consumidor homossexual?
}

\author{
Bodies tattooed: An expression of identity homosexual consumer?
}

\section{Resumo}

\author{
Mario José de Oliveira ${ }^{\mathrm{I}}$ \\ Irene Raguenet Troccoli ${ }^{2}$ \\ Joyce Gonçalves Altaf ${ }^{3}$
}

\begin{abstract}
Este artigo investigou o uso de tatuagens enquanto expressão da identidade do consumidor homossexual masculino, a centralidade do corpo para estes homens, como a tatuagem atua nessa centralidade, se a tatuagem compõe o seu eu estendido, se a escolha de tatuagens obedece algum tipo de padrão, e se há particularidades individuais intervenientes neste consumo. Os resultados mostram que, embora as tatuagens sirvam como expressão da identidade conforme são utilizadas na projeção das personalidades de seus donos e de seu modo de vida, de sentimentos especiais e da representação de eventos que lhes sejam relevantes, esta expressão nem sempre é relacionada à sexualidade.
\end{abstract}

Palavras-chave: Eu estendido; Tatuagem; Identidade.

\begin{abstract}
This paper investigates how tattoos are used as an expression of male homosexual identity, the body centrality for these men, the influence of tattoos on this centrality, if the tattoo is used on the composition of the extended self, if gays choose tattoos obeying some sort of pattern, and if there are individual specificities that influence their consumption of tattoos. Although tattoos serve as an expression of identity since they are used to project their personalities, their way of life, their special feelings, and to represent events that are relevant to them, this expression is not always related to their sexuality.
\end{abstract}

Keyword: Extended self; Tattoo; Identity.

\footnotetext{
1 mario@cnpab.embrapa.br, Brasil. Mestre em Administração e Desenvolvimento Empresarial pela Universidade Estácio de Sá - UNESA. Rodovia Antiga Rio-São Paulo, KM 47, ECOLOGIA, CEP: 23890-000 - Seropédica, RJ - Brasil.

2 irene.troccoli@estacio.br, Brasil. Professora Titular da Universidade Estácio de Sá - UNESA. Doutora em Administração de Empresas pela Pontifícia Universidade Católica do Rio de Janeiro - PUC-Rio. Av. Pres. Vargas, 648, Centro, CEP: 20071-001 - Rio de Janeiro, RJ - Brasil.

3 jgaltaf@yahoo.com.br, Brasil. Professora da Faculdades Integradas Vianna Júnior - FIVJ. Mestre em ração e Desenvolvimento Empresarial pela Universidade Estácio de Sá - UNESA. Av. Pres. Vargas, 648, Centro, CEP: $20071-001$ Rio de Janeiro, RJ - Brasil.
}

Recebido em 12.01.2013

Aprovado em 15.03.2013

Revista Administração em Diálogo

ISSN 2178-0080

Programa de Estudos Pós-Graduados em Administração

Pontifícia Universidade Católica de São Paulo 


\section{Introdução}

A cultura é o meio pelo qual a identidade, os anseios e o significado das normas e das tradições repartidas pelos consumidores podem ser determinados, consequentemente tornando-se construto importante para os estudos do comportamento desses indivíduos. Por seu turno, uma subcultura pode ser entendida como um tipo especial de comunidade onde, por serem compartilhados experiências e valores comuns a todos aqueles que ali se encontram, as relações de consumo e as posses dessas pessoas adquirem caráter mais específico (KARSAKLIAN, 2009).

Como o consumo não tem a ver somente com a aquisição em si, tampouco com a usufruição do bem ou serviço comprado nem com seu eventual descarte (PEREIRA, 2009), a cultura, assim como o estilo de vida, exerce papel na construção das identidades. Afinal, consumir pode simbolizar algo mais para o indivíduo do que apenas adquirir algo, remetendo à formação, à manutenção e ou à reformulação de sua identidade enquanto ser social (BELK, I988). Ou seja, informações sobre as pessoas podem advir de suas posses, assim como dos grupos aos quais elas venham a pertencer, ou, mesmo, de seu comportamento relacional com a sociedade (PEREIRA, 2009).

Nesta linha de raciocínio, grupos sociais, como o dos homossexuais, apresentam uma cultura e uma subcultura que imprimem significado simbólico ao consumo de seus bens e serviços. Isto se dá porque cultura e subcultura constituem importantes fontes de variação neste consumo, quaisquer que sejam os indivíduos. Por seu turno, a identidade homossexual se torna importante sob a ótica do consumo e do Marketing porque os indivíduos homossexuais que assumem esta identidade poderão expressar seu "eu" por meio de posses (NUNAN, 2003). E, ao fazê-lo, eles poderão utilizar o próprio corpo nesta extensão: Pereira e Ayrosa (2OIO, 20I2) observaram que o corpo é uma posse de grande valor no mundo homossexual, especificamente, masculino.

Estendendo essa forma de pensar ao mundo do consumo daquilo que é simbólico, chega-se às tatuagens, iniciativa que pode ser vista como instrumento à construção do corpo e ao estabelecimento da identidade que remete a um subgrupo (PERES, 2005; PHILLIPS, 2003), assim como um exercício do controle individual sobre o corpo (LEITÃO, 2004). 
De fato, Anjos (2000) ressalta que os homossexuais masculinos provenientes das chamadas classes médias urbanas procuram romper com a percepção do indivíduo inferior e feminino, adotando uma imagem construída a partir de signos da masculinidade - por exemplo, o corpo musculoso. Fazendo-lhe eco, Pereira e Ayrosa (2OIO, 2OI2) destacam a corpolatria como um dos pontos mais marcantes da cultura homossexual masculina: o culto a um corpo construído possui a dupla função de comunicar um enquadramento nos padrões culturais da identidade homossexual, bem como administrar o estigma associado à homossexualidade. Assim, o comportamento de consumo destes homens também pode ser interpretado como reformulação de sua identidade, como um sinal de poder ou como uma ferramenta para alcançar visibilidade e reconhecimento (KATES, 2000; BELK, I988).

Este artigo objetivou verificar como se dá o uso de tatuagens enquanto expressão da identidade do consumidor homossexual masculino assumido ${ }^{4}$. Para tanto, ele averiguou a centralidade do corpo para este público e a forma como a tatuagem atua nessa centralidade. Também foi estudado se a tatuagem compõe o eu estendido do homossexual masculino, se sua escolha obedece a algum tipo de padrão, e se há particularidades individuais intervenientes no consumo de tatuagens por parte destes homens.

Este artigo está dividido em cinco partes: essa introdução; revisão bibliográfica referente a identidade, a eu estendido, a tatuagem e sua associação ao eu estendido, a homossexualidade e homossexuais, e a corpolatria; o método utilizado; os resultados da pesquisa de campo; e a conclusão e as limitações do estudo, assim como as recomendações para futuros trabalhos.

\section{Referecial Teórico}

\section{Identidade}

O conceito de identidade advém da necessidade de um senso de quem se é em conjunto com mudanças em contextos sociais (HOWARD, 200o). Referindo-se

\footnotetext{
4 Nesta pesquisa o termo gay é usado como sinônimo de homossexual masculino, e por gays assumidos entenderam-se homens que convivam harmonicamente com sua homossexualidade

Revista Administração em Diálogo ISSN 2178-0080

Programa de Estudos Pós-Graduados em Administração

Pontifícia Universidade Católica de São Paulo
} 
basicamente a experiências psicológicas, obviamente contém alto grau de subjetividade, envolvendo níveis de autorepresentação individual e em grupo. Consequentemente, não se pode supor que a identidade traga uma unidade em sua essência: antes, ela é multifacetada, sendo formada por autorepresentações diferentes entre si (DITTMAR, 2007).

Para Hall (2006), atualmente novas identidades surgem e fragmentam o indivíduo, anteriormente visto como único. Isto se dá porque, à medida que os sistemas de significação e de representação cultural se multiplicam, o ser humano é confrontado por uma multiplicidade desconcertante e cambiante de identidades possíveis, com cada uma das quais ele se poderia identificar, nem que temporariamente.

Não estranha que, nesse contexto, o consumo se tenha tornado um meio moderno para o indivíduo adquirir, expressar e tentar melhorar sua identidade (DITTMAR, 20O7). Isso porque é através do simbolismo dos produtos que definem a imagem do consumidor que esse último pode se autorepresentar e, finalmente, se aproximar - ou não - de uma imagem considerada ideal, conforme traz, em si, a representação daquilo que intimamente se deseja: sucesso, felicidade, glamour.

Assim é que, por meio das modernas formas de consumir, as pessoas podem adquirir, expressar e tentar melhorar sua identidade, já que essas ações passam a traduzir status social e a representar traços específicos da personalidade do indivíduo. Vale notar a consequência dessas ações que visam a se alcançar uma identidade cada vez mais ideal: o incentivo à aquisição de imagens que possibilitem às pessoas se apropriarem dos significados simbólicos. Com isso, o consumo passa a transcender a simples obtenção de coisas, e passa a significara aquisição de uma identidade. As posses configuram-se, então, em pontes não de quem se é, mas de quem se gostaria de ser (McCRAKEN, I988).

Nessa linha, remete-se ao self, identificado como “[...] aquilo que define a pessoa em sua totalidade” (DORON; PAROT, I998, p.34). Corroborando essa visão, CavalletMengarelli (2008, p.22) ressalta que "O self é a pessoa enquanto lugar da atividade psíquica em sua totalidade”, sendo dessa forma, à primeira vista, difícil de ser acessado e mensurado. Não obstante esta característica, o self tem sido amplamente estudado tanto pela psicologia quanto pelo Marketing - neste último caso, mais especificamente na área 
de comportamento do consumidor - por sua eficácia enquanto instrumento para o aprofundamento do estudo das motivações ao consumo de bens e de serviços.

Por consequência, mais do que auxiliar no desenvolvimento e na reafirmação do self, o consumo age como um identificador do indivíduo na sociedade (WATTANASUWAN, 2005). Com isso, o simbolismo dos objetos e dos serviços consumidos passa a ser mais importante do que sua própria utilidade, fenômeno que converge com a pletora de signos e de imagens que permeiam a sociedade contemporânea (BELK, I988; WATTANASUWAN, 2005).

Vale notar que o consumo pode não ser a única forma de o indivíduo buscar e construir sua identidade, ou de garantir sua existência. Experiências de alto impacto emocional também teriam esse efeito, muito embora fazer compras tangencie a autoexpressão quando se configura em uma busca por significado, por satisfazer vontades do self. Dessa forma, o "eu" pós-moderno ou contemporâneo, tradicionalmente aberto e flexível, seria capaz de se recriar a sim mesmo por meio da grande oferta de novos produtos na sociedade de consumo (BARBOSA; CAMPBELL, 20O7).

Por seu turno, o consumismo pode ser visto como ligado à crise de identidade, por exemplo, por meio da ideia de que a aquisição de um bem possa ser sinônimo de solução para um problema de identidade: o “[...] eu não é uma percepção de autenticidade, e sim uma situação calculável de sobrevivência e sucesso social” (SLATER, 2002, p. 87). Enquanto a humanidade está em busca da construção e da manutenção da identidade, essa última deve ser forjada para os diversos meios de interação dos indivíduos, aí incluídos os relacionamentos sociais, de trabalho e até mesmo íntimos.

É nesta linha de raciocínio que Baudrillard (I973) remeteu ao consumo como um processo de satisfação das necessidades que nem sempre existiu da forma contemporânea: na Idade Média, apesar de os indivíduos comprarem, gastarem e usufruírem, não existia consumo, com a relação entre os objetos e a coletividade sendo então muito voltada para o valor de uso dos objetos, sem existir valor simbólico. A partir da Revolução Industrial, as necessidades e os desejos do consumidor passaram a gerar ciclo de oferta e demanda, raciocínio reforçado por Twitchell (200o) quando este diz que o surgimento da sociedade de consumo implicaram crescimento forte da oferta e da 
demanda. Com isto, consolidou-se o desejo de consumir, que já habitava há muito tempo as mentes dos indivíduos, ocorrendo o que Lipovetsky (I989) classificou como Revolução do Consumo. A lógica por trás deste movimento reside na combinação perfeita entre a concorrência inerente aos meios de produção para atender aos desejos dos consumidores, e a luta pela distinção por meio da busca por novidades que confiram um distintivo diferenciado para quem consome (BOURDIEU, I98I).

Veblen (I899) sugeriu que essa mobilidade encontrada na raiz do consumo vem desde as sociedades ditas predatórias, residindo na rivalidade entre os homens, no desejo de posicionar-se vantajosamente em relação aos outros e de prevalecer sobre eles. Desde então, a relação abstrata entre os objetos, a coletividade e o mundo passou a ditar as leis do consumo. Segundo este autor, o que é consumido nunca é o objeto, mas sim essa relação com os objetos. Baudrillard (I973) complementa: os produtos materiais não são objetos de consumo, são apenas objetos da necessidade e da satisfação. O consumo, antes um ato simbólico do que econômico (ROCHA, 1995), [...] é a totalidade virtual de todos os objetos e mensagens constituídos em um discurso cada vez mais coerente. É uma atividade de manipulação sistemática de signo. (BAUDRILLARD, I973, p. 66)

Com a consolidação do consumo iniciou-se o poder social dos signos (BOURDIEU, I98I). A simples posse de uma novidade conferia, ao indivíduo, um caráter de distinção social. As pequenas e sucessivas modificações de detalhes passaram a caracterizar a moda, que traduz uma descontinuidade histórica, uma quebra na lógica imutável da tradição, própria das sociedades primitivas (LIPOVETSKY, I989).

É o código presente em cada objeto e em cada relação de consumo que classificará o indivíduo que o consome. A concorrência entre as classes e a luta pela distinção sustentam a efemeridade do consumo, fazendo com que os consumidores estejam sempre procurando inovações e deixando para trás o que não é mais novidade (BAUDRILLARD, I98I; BOURDIEU, I98I). Lipovetsky (I989) não só sugere que as classes dominantes ditaram o início do consumo, como defende que esse processo de imitação e de distinção continua a existir até hoje, sendo o responsável por ditar os modelos de comportamento que passam de uma classe a outra.

Com o passar do tempo, os produtos deixaram de se diferenciar por suas características intrínsecas para apresentarem uma diferenciação pelo simbólico atribuído 
a eles e à sua marca (ROCHA, I995). A partir do momento em que o objeto começa a significar algo a mais que a sua materialidade, ele ganha o caráter de signo, que adquire coerência e sentido em uma relação abstrata com outros objetos-signos (BAUDRILLARD, I973).

Os objetos adquiridos passam a ter um valor de diferenciação entre os homens. É o próprio significado dos objetos que promove a diferenciação entre eles mesmos e os indivíduos que os consomem. O domínio do consumo é onde homens e objetos são postos em contato, adquirindo sentido, produzindo significações e distinções sociais (ROCHA, I984). É esta sociologia da diferença que traduz uma procura social objetiva de sinais e diferenças, funda o consumo, não como função de uma satisfação individual, mas como uma atividade social (BAUDRILLARD, I98I).

É nesse contexto que se pode situar a identidade sexual, que remete à experiência interna do papel sexual do indivíduo, ao senso de si mesmo como homem ou como mulher, incluindo aquilo que se sente, que se faz ou que se pensa, no sentido de indicar, a quem quer que seja, que se é masculino ou feminino (TUCKER; MONEY I975). Isso quer dizer que essa identidade em especial detém o mesmo peso que outros fatores sociológicos quando se trata da aquisição de um serviço ou de um produto físico, tendo em vista que se trata de elemento que pesará nas escolhas desses últimos, dandolhes uma conotação sexuada (KARSAKLIAN, 2009).

Ainda nesse aspecto, vale notar a importância da percepção da diferença, em termos de contraste ou de oposição, para a construção de uma identidade. Se o formato da identidade está relacionado tanto à maneira como os indivíduos se definem quanto à imagem que o outro lhes transmite acerca de si mesmos, para identificar-se como pertencente ou não ao mesmo grupo é necessário manter contato com um indivíduo diferente (LANDOWSKI, 2002).

Tatuagem e sua associação ao eu estendido

"O eu estendido consiste no eu somado às posses; isto é, as pessoas tendem a definir a si mesmas em parte por meio das posses. Assim, algumas posses não são apenas manifestações da autoimagem de uma pessoa; são parte integral de sua autoidentidade.” (HAWKINS; MOTHERSBAUGH; BEST, 2007, p. 229), Partindo dessa afirmação, 
infere-se que o que se possui é, com os devidos limites, aquilo que se é. Ipso facto, ao perder suas posses mais importantes um indivíduo se transforma, ainda que de forma parcial.

Produtos e papeis sociais podem estar associados, e de forma contundente, a atividades de consumo já que essas podem ser entendidas como uma maneira de se expressar uma identidade ou de definir seu eu, conforme o consumidor aprende que um papel social se associa a produtos e a atividades que os reforçam, ajudando na sua definição (SOLOMON, 2OII). Ao mesmo tempo,

Muitos produtos são fundamentais para o desempenho dos papéis e podem ser vistos como uma extensão da identidade da pessoa (conceito do "eu estendido") no nível individual que incorpora os objetos pessoais - "você é o que você consome" [...] Os objetos pessoais, ou bens, usados para definir papéis sociais e que são usados como parte da pessoa compreendem o "eu estendido" e ajudam a formar a identidade do consumidor.(VALENTE, 2006, p. 67)

É nesse contexto que se pode inserir o consumo de tatuagens. A interpretação desse adorno corporal como metáfora de uma conversa entre o "eu" e o "meu", interligando o "eu" com a personalidade do indivíduo, faz com que sirva à definição de identidades autênticas e de escolhas. Daí pode-se entender o desejo de adquirir uma tatuagem como a vontade de "reescrever-se", concretizando o desejo, por exemplo, de passar a se comportar de maneira diferente em certo estágio de sua vida, ou quando os valores mudam. A imagem corporal, enquanto construção mental do corpo físico, ou a maneira como as pessoas vêem seus corpos, remetem ao enquadramento de características tanto de personalidade quanto de atributos físicos como inatas do indivíduo, podendo ser construídas a partir de escolhas individuais (ALCINA, 2009).

Tatuagens são adornos individuais. Por isso, podem ser consideradas um modo supremo de self, assim como podem simbolizar algum tipo de compromisso, seja com estilo de vida, seja com determinado grupo (GOULDING et al., 2004). Isso explica por que as tatuagens, assim como uniformes, piercings e propriedade (por exemplo, motos) têm sido interpretadas como manifestação de pertencimento a subculturas -marinheiros, militares, criminosos, homossexuais - servindo para integrar identitariamente um indivíduo a um grupo, distinguindo-o dos não membros (FOLLETT, 20o9; PHILLIPS, 2003).

Outra forma de se compreender o uso das tatuagens é como estratégia de 
construção do corpo, atitude que pode se dar por meio do consumo e ou de procedimentos que denotem inconformidade ou atitude revolucionária (PERES, 2005). Como esse processo perpassa a construção de identidades conforme papeis sociais e padrões de beleza vigentes são buscados e adotados, as tatuagens podem atuar como um simbolismo, trazendo a percepção de identidade ao traduzirem a forma como uma pessoa se vê (ALCINA, 2009).

Já o enfoque antropológico a esse respeito entende que, transmitidas através das gerações, as técnicas corporais reforçam os fundamentos culturais de uma sociedade. Nesse aspecto, a tatuagem adequa-se à sociedade contemporânea, já que se trata de caracterização naquilo que representa papel central na vida das pessoas - o corpo. Por outro lado, esse adorno contraditoriamente também passa para o âmbito da cultura, à medida que molda o corpo físico (LEITÃO, 2004). Assim é que a tatuagem contribui na criação da identidade dos indivíduos quando tangencia a teoria de Belk (I988) relacionada à definição do self e ao consumo simbólico: ela serve a diversos propósitos, tais como manifestar rebeldia, marcar a afiliação a um grupo, comemorar um evento de vida e registrar voto de relacionamento (SHELTON; PETERS, 2008).

Não estranha que, à luz de tantas representações atribuídas à tatuagem, existam diversos estudos - elaborados fora do Brasil - que, ao ressaltarem a reemergência do corpo nas pesquisas sobre o comportamento do consumidor, a liguem ao fenômeno do consumo, a exemplo de Veliquette, Murray e Evers (1998), Hawkins, Mothersbaugh e Best (20O7) e Warlop e Beckman (200I). Contudo, ao fazê-lo, os autores normalmente têm em mente as fortes diferenças entre o estudo do consumo de tatuagens e as tradicionais pesquisas de comportamento dos consumidores. Isso porque o processo de ser tatuado costuma ser uma experiência dolorosa e permanente, de aquisição não trivial, e que apresenta aspectos únicos por se tratar do resultado de uma interação entre o símbolo, o artista, o local do corpo e o tipo de corpo (VELIQUETE; MURRAY; EVERS, 2006).

Não por outro motivo, diferentemente de objetos que compõem o eu estendido, a tatuagem está no corpo e participa da construção da identidade do indivíduo, já que não raro sua composição tem a ver com o passado do seu portador, podendo ajudar na criação de mitos e no próprio enriquecimento pessoal do indivíduo (LEITÃO, 2004; 
CESARE, 2OII).

\section{Homossexualidade e homossexuais}

Tebar e Rosseti (2004), num breve histórico da homossexualidade, destacam que, em alguns períodos, ela esteve em moda, principalmente na Grécia, quando foi considerada tão normal quanto a heterossexualidade, não sendo estigmatizada ou hostilizada. Em outros, o simples fato de alguém ser apontado como homossexual era suficiente para ser assassinado, como durante o final da Idade Média a partir de punições impostas pela Igreja Católica.

O início do século XX também permaneceu desfavorável para os homossexuais, até que, nos anos de r96o, os movimentos estudantis e sociais em favor da paz, da liberdade e do amor favoreceram a luta por direitos relacionados à sexualidade humana. Em seguida, na década de I980, a epidemia de AIDS foi associada aos homossexuais como grupos de risco, trazendo mais estigmas e discriminação social. Tebar e Rosseti (2004) reforçam que, ao início do século XXI, os homossexuais permaneciam sofrendo discriminações, com alguns indivíduos sentindo-se à vontade para vivenciar sua sexualidade apenas em guetos exclusivos. No momento, a luta contra o preconceito está numa nova fase: os homossexuais - homens e mulheres - começam a se expor e a se destacar (ALTAF; TROCCOLI, 2OII), por exemplo com crescente exposição na mídia.

Em que pese este crescimento da visibilidade dos homossexuais - tanto masculinos como femininos - na sociedade, seu perfil sócio-demográfico ainda carece de informações mais fidedignas no País. Poucas pesquisas são feitas para melhor conhecêlos, seja pelo ângulo de sua composição, seja por suas preferências, e as que existem são desenvolvidas por órgãos de pesquisa não oficiais e normalmente restritas a uma parte apenas desta grande população (ALTAF; TROCCOLI, 2OII). Por conseqüência, estudos sobre as preferências e tendências de consumo destes indivíduos normalmente se dão em bases menos sólidas do que o ideal. Por exemplo, em 2007 o Movimento Gay ${ }^{5}$ entendia que a participação do público $\mathrm{GLS}^{6}$ no total da população brasileira alcançava ıo\%, o que significaria, hoje em dia, cerca de I9 milhões de pessoas (MOVIMENTO GAY, 2007).

\footnotetext{
5 Termo referente a manifestações sociopoliticoculturais em favor do reconhecimento da diversidade sexual, e pela promoção dos interesses dos homossexuais diante da sociedade brasileira.

6 Gays, lésbicas e simpatizantes
}

Revista Administração em Diálogo

ISSN 2178-0080

Programa de Estudos Pós-Graduados em Administração

Pontifícia Universidade Católica de São Paulo 
Este percentual é repetido por Tsuji et al. (2007, p. I), remetendo ao IBGE, embora sem especificar esta referência: “[...] o público gay representa Io\% da população do Brasil”. Finalmente, Irigaray (2007, p. 2) diz que "[...] no Brasil, vivem aproximadamente (...) I8,2 milhões de cidadãos homo ou bissexuais”.

Apesar destas dificuldades, Pereira e Ayrosa (2012) ressaltam que, embora de forma ainda tímida, as áreas de comportamento do consumidor e de Marketing parecem também acompanhar o interesse em estudar o consumidor gay, sendo exemplos disso os trabalhos de Pereira, Ayrosa e Ojima (2006) e de Altaf e Troccoli (2OII).

\section{Corpolatria}

$\mathrm{Na}$ medida em que o corpo pode simbolizar grupos sociais, assim como pode garantir status e ou reconhecimento àqueles que alcançam forma física digna de admiração, ele passa a ter elevada relevância para o posicionamento social dos indivíduos (GOLDENBERG, 2007). Isso significa que o corpo exerce dupla função enquanto artefato simbólico, porquanto pode ser simultaneamente usado para a construção identitária assim como para a transmissão de uma mensagem, na medida em que sua posse é utilizada para a comunicação de quem se é (SCHOUTEN, I99I).

Segundo Goldenberg (2007), o corpo possui grande importância para o indivíduo se colocar na sociedade, visto que pode simbolizar grupos sociais, conferindo status e ou reconhecimento pelo esforço de quem alcançou uma chamada "bela forma". Desta forma, o corpo constitui um artefato simbólico utilizado tanto na construção da identidade quanto na transmissão de uma mensagem; ou seja, o indivíduo lança mão de seu corpo, como se fosse uma posse, para comunicar quem é (SCHOUTEN, I99I).

Assim, o corpo enquanto posse lhe implica a capacidade de ser modulado, ação que pode ser exercida de diversas formas, seja por meio de cirurgias plásticas, de manipulação estética, de anabolizantes, de dietas, de exercícios físicos, e, até mesmo, de tatuagens. Não por acaso, o corpo passou a ser considerado como um dos principais símbolos na extensão do "eu” ou do self, e na reconstrução de uma identidade (BELK, I988). E, por extensão, essa imagem corporal - que pode até mesmo ser distorcida, com o indivíduo se achando mais alto, mais magro ou mais musculoso do que realmente é pode se constituir em uma parte do seu próprio autoconceito, conforme se trate de uma 
construção subjetiva sobre seu físico (SOLOMON, 2OII).

De fato, a visão do corpo como posse, passível de modulação - por meio de manipulação estética, de cirurgias plásticas, de dietas, de exercícios físicos, de anabolizantes, e de tatuagens - foi reportada por Belk (1988), que considera que o corpo é um dos principais símbolos utilizados na extensão do "eu" ou do self, e na reconstrução de uma identidade. Não por acaso, para Solomon (2OII) a imagem corporal de um indivíduo constitui uma parte de seu autoconceito, pois é uma construção subjetiva do consumidor sobre seu físico, podendo ser inclusive uma imagem distorcida - o indivíduo pode se achar mais alto, mais magro ou mais musculoso do que realmente é.

Por consequência, a catexia corporal - conjunto de sentimentos de um indivíduo sobre suas posses no caso daqueles relacionados ao próprio corpo - torna-se construto de importância destacada para o Marketing, já que o sentimento que um consumidor tem com relação a uma parte do seu corpo a partir da imagem do ideal de beleza naquela cultura pode lhe influenciar o padrão de consumo (SOLOMON, 2OII).

E, enquanto o conjunto de sentimentos de um indivíduo sobre suas posses é chamado de catexia, quando se trata dos sentimentos relacionados ao próprio corpo o termo adotado é catexia corporal. Esta última torna-se relevante para o Marketing porquanto o padrão de consumo de um indivíduo pode ser influenciado pelo sentimento que ele tem com relação a uma parte do seu corpo que seja influenciada pela imagem correspondente ao ideal de beleza em sua cultura (SOLOMON, 2OII).

O que se conclui dessa linha de raciocínio é que a pressuposição de Belk (I988) de que o corpo é uma forma de construção e ou de reconstrução da identidade encaixa-se perfeitamente na propositura de que a identidade pode ser criada e ou transformada por meio do consumo, seja de bens ou de serviços. Não fosse assim, não se observariam as consequências que uma cirurgia plástica estética podem ter sobre os pacientes, ao lhes aumentar o conforto nas identidades que já possuem (PHILLIPS, 2003).

Portanto, sabendo-se que a identidade pode ser criada e ou transformada por meio do consumo de posses (bens e ou serviços), quando este consumo é relativo ao corpo observa-se claramente a pressuposição de Belk (I988) de que o corpo é uma forma de construção e ou de reconstrução da identidade. A cirurgia plástica ou estética constitui o mais drástico exemplo de como isto pode ser feito, visto que pode tornar as 
pessoas mais confortáveis nas identidades que já possuem. Ou pode agir como um veículo para a mudança física, com a mudança resultante podendo fornecer maior confiança, sensação de controle e até mesmo energia (PHILLIPS, 2003).

E é por meio da incessante corrida em busca da beleza ideal, ditada pela supremacia da aparência, que os sujeitos, marcados especialmente pela insatisfação com o próprio corpo, procuram construir suas identidades e autoimagens particulares (TRINCA, 2008) e, em seus respectivos grupos sociais, adequar-se às normas de aparência física ditadas pela mídia e pelo mercado (WARLOP; BECKMANN, 2OOI).

Se este comportamento pode ser observado em diversos grupos sociais, as pressões para se ter o corpo perfeito são mais fortes dentro da comunidade homossexual masculina do que em outras comunidades (MEANY-WALEN; DAVIS-GAGE, 2009). Nela, o corpo possui grande valor, e esta hipervalorização parece ser um dos códigos de identificação interna deste grupo, existindo uma pressão estética sobre os indivíduos que entram neste mundo (PEREIRA, 2009). Desta forma, para se adaptar às "normas" da cultura gay, estes indivíduos percebem que o corpo é uma posse que pode ser manipulada, enquanto passaporte para ser aceito e pertencer ao grupo.

Completando este raciocínio, existem três chamados pré-requisitos básicos relacionados ao corpo na comunidade homossexual masculina - magreza, musculosidade e atratividade - que estão intimamente associados à preocupação com aceitação na comunidade, à necessidade e ou à possibilidade de conseguir relacionamentos estáveis, e ao medo da solidão (MEANY-WALEN; DAVIS-GAGE, 2009).

Pereira (2009) propõe outra causa para a corpolatria no mundo homossexual masculino: uma maior preocupação com a saúde após a emergência da AIDS nas décadas de 1980 e I990. Já Gontijo (2007) a atribui à maior abertura, ocorrida nas últimas décadas, para a assunção de uma identidade gay, o que teria levado os indivíduos desse grupo a querem ser reconhecidos como cidadãos “normais”. Finalmente, Pereira (2009) propõe que a corpolatria seria uma forma de enfrentamento e ou de resistência à exclusão social e ao estigma associado à identidade homossexual.

Outra visão sobre este tema pode ser obtida em Hospers e Jansen (2005). Para estes autores, a pressão de viver de acordo com os padrões de atratividade observados dentro da comunidade homossexual masculina constitui um fator estressante, visto que 
os indivíduos estão em constante contato com mensagens internas do tipo "eu não me encaixo na sociedade e somente serei aceito na comunidade gay quando possuir os padrões físicos aceitáveis". Corroborando esta proposta, os autores observaram, no meio homossexual masculino, uma alta correlação entre orientação sexual, satisfação pessoal com o corpo e a incidência de distúrbios alimentares, representada pela insatisfação com o corpo associada ao desenvolvimento de hábitos potencialmente insalubres de exercício e de dieta.

\section{Método}

No presente estudo, de abordagem qualitativa, foram entrevistados homens gays assumidos residentes na cidade do Rio de Janeiro, que possuíssem pelo menos uma tatuagem, completa ou em processo de confecção, e que se encaixassem, ou não, no estereótipo sarado $^{78}$. A seleção destes sujeitos se deu por meio da técnica de amostragem por bola de neve (AAKER; KUMAR; DAY, 2004; RUDD, I996), enquadrando-se na seleção de categoria intencional, já que os sujeitos-tipo foram "[...] selecionados por representarem as características relevantes da população em estudo" (THIRYCHERQUES, 2009).

A pesquisa de campo se deu no primeiro semestre de 20I2, tendo sido precedida por pré-teste com dois homens que se enquadravam no estereótipo desejado. À exceção de um entrevistado, os encontros com todos os demais foram realizados em horário de lazer na praia.

O número de entrevistados, que chegou a oito, convergiu com a colocação de McCracken (I988) de que a seleção de respondentes para longas entrevistas deve obedecer ao princípio de que “menos é mais": para este autor, é mais importante trabalhar-se mais longamente e com maior cuidado com menos pessoas do que mais superficialmente com muitas pessoas, sendo oito respondentes perfeitamente suficientes para muitos projetos de pesquisa.

7 De acordo com o senso comum, ser sarado significa apresentar distrofia muscular generalizada, no sentido de ter corpo definido, "malhado", sem acúmulo de gorduras em algumas partes - principalmente no abdômen. 0 termo foi adotado pelo pesquisador por ser usual no jargão das pessoas que cultuam o físico, tendo sido compreendido pelos entrevistados sem maiores problemas, incluindo aqueles que não praticam atividade física

${ }^{8}$ Esta preocupação visou a evitar viés trazido pela provável unicidade na concepção de centralidade do corpo que se teria se todos os entrevistados fossem homens que cultuam o físico

Revista Administração em Diálogo

ISSN 2178-0080

Programa de Estudos Pós-Graduados em Administração

Pontifícia Universidade Católica de São Paulo 
Os resultados das conversas - que foram gravadas - foram em seguida submetidos a uma variante da técnica da análise de discurso $(\mathrm{AD})$, denominada de $\mathrm{AD}$ soft, ou análise interpretativa das entrevistas, que reproduziu os procedimentos adotados por Damascena e Farias (20I3) em sua pesquisa.

Também houve contato com dois tatuadores profissionais atuantes na cidade do Rio de Janeiro, aos quais se perguntou, especificamente, sobre as preferências de seus clientes gays quanto à escolha de figuras.

\section{Resultados da Pesquisa de Campo}

As características pessoais dos oito entrevistados podem ser vistas no Quadro I, assim como as características identificadas em suas respectivas tatuagens. Verifica-se que as idades oscilaram entre o mínimo de 2r anos e o máximo de 35 anos, e que as profissões são variadas. Em termos de cuidados físicos, três deles (entrevistados A, E e G) se enquadravam no estereótipo sarado. Dentre os demais cinco, um (entrevistado F) declarou nunca ter sido adepto de treinamento físico, e os restantes quatro o fazem de forma mais moderada.

No que tange ao número de tatuagens por entrevistados, a média foi de 2,I. Fazendo-se uma análise entre a quantidade per capita de tatuagens e desenvolvimento físico do entrevistado, vê-se que não há uma relação direta a priori: enquanto o sujeito com o maior número de desenhos (entrevistado A) é sarado, os dois outros (entrevistados C e F), com três desenhos cada, se apresentam como não sarados, da mesma forma que os demais dois sarados (entrevistados E e G) apresentam, respectivamente, um e dois desenhos. Quanto à localização das tatuagens, a superfície preferida foram as costas, seguidas dos braços, do abdômen e dos pés e a perna. 
Quadro I. Perfil dos homossexuais masculinos entrevistados e características das respectivas tatuagens

\begin{tabular}{|c|c|c|c|c|c|c|c|c|c|}
\hline $\begin{array}{l}\text { Entrevis- } \\
\text { tado }\end{array}$ & $\begin{array}{l}\text { Idade } \\
\text { (anos) }\end{array}$ & Profissão & $\begin{array}{c}\text { Prática de } \\
\text { atividade } \\
\text { física } \\
\end{array}$ & Sarado & $\begin{array}{c}\text { Quantida- } \\
\text { de de } \\
\text { tatuagens }\end{array}$ & Localiza-ção & $\begin{array}{c}\text { Tama-nho } \\
(\mathrm{cm})\end{array}$ & $\begin{array}{c}\text { Colorida ou } \\
\text { monocromática }\end{array}$ & Desenho \\
\hline $\mathrm{A}$ & 26 & Militar & Intensa & Sim & 4 & Braços e costas & 20 & $\begin{array}{c}\text { 1. Uma colorida } \\
\text { 2. Três } \\
\text { monocromática(s) }\end{array}$ & $\begin{array}{c}\text { 1. Frase de música } \\
\text { 2. Nome da mãe, tribal, } \\
\text { inicial do nome de ex- } \\
\text { namorado } \\
\end{array}$ \\
\hline B & 31 & $\begin{array}{c}\text { Produtor de } \\
\text { TV }\end{array}$ & $\begin{array}{c}\text { Já foi } \\
\text { intensa, } \\
\text { atualmente } \\
\text { não pratica }\end{array}$ & Não & 2 & Braços, costas & 15 & Monocromáticas & Estrela e gato \\
\hline $\mathrm{C}$ & 28 & Salva-vidas & Moderada & Não & 3 & $\begin{array}{c}\text { Braços, costas, } \\
\text { abdômen }\end{array}$ & 33 & Coloridas & $\begin{array}{c}\text { Gato, mandala e nome do } \\
\text { ex-parceiro }\end{array}$ \\
\hline $\mathrm{D}$ & 35 & Balco-nista & $\begin{array}{c}\text { Já foi } \\
\text { moderada, } \\
\text { atualmente } \\
\text { não pratica }\end{array}$ & Não & 1 & Costas & 23 & Monocromática & Dragão \\
\hline$E$ & 23 & Modelo & Intensa & Sim & 1 & Abdômen & 13 & Colorida & Pimentas \\
\hline $\mathrm{F}$ & 32 & $\begin{array}{l}\text { Adminis- } \\
\text { trador }\end{array}$ & $\begin{array}{c}\text { Nunca } \\
\text { praticou }\end{array}$ & Não & 3 & Braços, costas, pé & 45 & Monocromáticas & Tribal \\
\hline G & 24 & $\begin{array}{l}\text { Guia de } \\
\text { turismo }\end{array}$ & $\begin{array}{l}\text { Média a } \\
\text { intensa }\end{array}$ & Sim & 2 & Costas & 40 & $\begin{array}{c}\text { 1. Uma } \\
\text { monocromática } \\
\text { 2. Uma colorida }\end{array}$ & $\begin{array}{l}\text { 1. Religiosa (Mantra) } \\
\text { 2. Religiosa (Mantra) }\end{array}$ \\
\hline $\mathrm{H}$ & 21 & Vendedor & Moderada & Não & 1 & Perna & 40 & Monocromática & Religiosa (Mantra) \\
\hline
\end{tabular}

Fonte: Elaboração própria

Nota: Como tamanho considerou-se apenas a largura horizontal dos desenhos de extremos (do início ao fim) medida com fita métrica. Para os entrevistados com mais de uma tatuagem foi considerado o somatório da largura horizontal de cada uma.

No caso das formas dos desenhos, as escolhas variaram muito entre os oito entrevistados: dois utilizaram nome ou frase, e todos utilizaram figuras. No caso destas últimas, as únicas semelhanças (embora com formas diferentes) se deram em termos de figuras tribais, de representação de gato e de figuras religiosas (mantras), adotadas por dois entrevistados cada uma; as demais se distribuíram entre figura mitológica (fênix, dragão), astro celeste (estrela), planta (pimenta), símbolo gráfico (ideograma) e representação geométrica (mandala) (ver Apêndice I).

Antes de se partir para a análise propriamente dita das entrevistas é importante chamar-se a atenção para uma constatação surgida apenas ao final das conversas: a cada fim de contato entrevistador-entrevistado, a maioria destes últimos mencionou uma sensação de valorização e de alegria por terem tido a oportunidade de conversar sobre os temas tatuagem, identidade e sexualidade. A importância desta atmosfera remete ao que coloca McCracken (I988) sobre a arte de conduzir entrevistas qualitativas: ao fazê-lo o investigador "escuta" muitas coisas além daquilo que o entrevistado realmente diz - por exemplo, administração de impressões, hesitação de tópicos e distorções voluntárias. 
Mas estas coisas ouvidas também podem incluir uma influência positiva trazida por um certo relaxamento emocional. Neste sentido, na medida em que os entrevistados se sentiam bem falando a respeito do assunto - interpretando a conversa como uma oportunidade rara de se expressar sobre o tema - é legítimo supor-se que o conteúdo de suas respostas embutiu um maior componente de envolvimento, e, por tabela, de sinceridade:

Gostei muito do tema da pesquisa... Bom falar do significado de tatuagens, do que representam pra cada um e deixar de lado o estigma de que a tatuagem é algo marginalizado, adotado apenas por bandidos, prostitutas ou gays. Hoje em dia é uma arte na pele, independente do que a pessoa é. (Entrevistado D)

No que tange ao resultado das conversas quanto ao uso das tatuagens enquanto expressão da identidade do consumidor homossexual masculino assumido, o que a pesquisa de campo indicou foi que esta expressão pode ocorrer ou não. E que, no caso de ocorrer, isto pode se dar de duas formas: relativamente à pessoa do tatuado não necessariamente expressando sua sexualidade, ou diretamente ligada à homossexualidade. Ademais, o primeiro caso suplantou o segundo, no caso dos sujeitos deste levantamento. O entrevistado D, por exemplo, deixou claro que esta expressão não existia, com sua (única) tatuagem tendo sido escolhida apenas por ser considerada bonita: (...) o desenho não tinha importância, o importante era o conjunto de como ia ficar na pele, o propósito era me tatuar, o que fazer, isso não importava, queria usar meu corpo meio como um tela pra estampar uma arte. Acho que daí que vem a história de escolher um desenho qualquer. Olhei o dragão e resolvi tatuar. (Entrevistado D)

Também o entrevistado A deixou explícito que suas tatuagens não estão diretamente ligadas à sua identidade homossexual, sendo uma forma de expressar sua personalidade, sua forma de ver o mundo. Ou seja, trata-se de um enfoque muito mais "genérico" do que aquele ligado à sua sexualidade:

As minhas tatuagens são a minha identidade, elas representam a minha vida, meus momentos, as fases da minha vida, elas representam o que eu sou... É a maneira que eu busquei para exteriorizar os meus momentos, meus sentimentos. Tenho uma tatuagem colorida que representa a alegria, a felicidade, sou uma pessoa feliz, de bem com a vida (...) (Entrevistado A)

Esta forma de pensar fica ainda mais evidente quando o mesmo entrevistado, assim como o entrevistado G, são perguntados diretamente sobre uma eventual conexão dos seus desenhos com sua homossexualidade. Suas assertivas são muito positivas a respeito da separação entre sexualidade e representação da tatuagem: 
[Se vejo minhas tatuagens] como [sendo] um símbolo da minha sexualidade? Não, não vejo... Minha vida sexual não tem nada haver com as minhas tatuagens, eu fiz porque gosto do que tatuei. Todas elas têm um significado na minha vida, elas passam algo que é meu, algo íntimo. Se alguém me perguntar eu falo, mas nada [ $a$ ver] com a minha sexualidade. Sou gay e não preciso que saibam disso. As pessoas que quero que saibam [da condição gay] eu mesmo falo diretamente. Como falei antes, não tenho problemas com o fato de ser gay, mas minhas tatuagens representam minha personalidade, me representam, sendo eu heterossexual ou homossexual. (Entrevistado A).

A tatuagem é minha identidade, pela história que tem esse mantra e tudo (...) Nada voltado para sexualidade, muito pelo contrário, sou bem resolvido sexualmente falando, minha tatuagem representa um mantra, nada sexual... É uma coisa que eu jamais misturaria. (Entrevistado G)

Por outro lado, no caso dos entrevistados B e C ficou evidenciado que a tatuagem é utilizada subsidiariamente à construção de uma identidade de grupo - o que converge com a pesquisa de Shelton e Peters (2008) - e enquanto representação de sua identidade homossexual, podendo até remeter diretamente a relação amorosa com outro homem:

(...) minhas tatuagens [o entrevistado possui duas, uma estrela e um gato] são muito delicadas, são direcionadas pela minha opção sexual. Eu encaro minhas tatuagens de maneira delicada, e direcionadas mesmo ao homossexual, tipo a uma coisa que me identifique como gay para as pessoas... Elas representam não só minha homossexualidade, expressam quem exatamente eu sou, minha identidade e minha sexualidade. (Entrevistado B)

Todas as minhas tatuagens [o entrevistado possui très, um gato, uma mandala e o nome do ex-parceiro] são símbolos da minha homossexualidade, sim. [...] O nome do meu ex-namorado fica no pulso, até usando relógio não dá pra disfarçar. Todos perguntam quem é Ricardo, as pessoas já perguntam sabendo quem é... (Entrevistado C)

Vale frisar, no caso deste último extrato de discurso, a plena assunção da identidade homossexual por parte do entrevistado $\mathrm{C}$ representada na atitude extrema de tatuar o nome de seu (ex) parceiro homossexual. De fato, enquanto tatuar o nome do parceiro é comum entre os heterossexuais (FOLLET, 2009; SABINO; LUZ, 2006), não seria ilógico esperar-se que o estigma (ainda) associado à homossexualidade pudesse atuar como inibidor deste tipo de ação junto a um gay. Portanto, o fato de este entrevistado ter realizado esta ação reforça a capacidade de a tatuagem ser utilizada como posse na construção de uma identidade homossexual. Esta percepção encontra suporte em Le Breton (2002), que ressalta que a tatuagem pode ser entendida como uma posse 
adquirida em função das necessidades pessoais do indivíduo: ser diferente, ser aceito, construir uma identidade, declarar um sentimento, ser solidário a uma causa.

Passando-se à centralidade do corpo para os gays entrevistados e para a relação das tatuagens com este elemento, preliminarmente vale resgatar Pereira (2009), quando este diz que o corpo possui grande valor no mundo gay. A reboque desta constatação, o estereótipo sarado, significando um corpo bem definido e bem cuidado, torna-se um forte diferencial para se conseguir um parceiro e ser aceito. Sendo assim, em maior ou em menor grau, a centralidade do corpo veio à tona em todas as entrevistas desta pesquisa, muito embora em intensidade modulada de acordo com a personalidade e com a vivência de cada indivíduo. Os extratos abaixo são exemplares, porquanto o entrevistado A se encaixava no estereótipo sarado, contrariamente aos três outros:

No meio gay o corpo faz parte do processo de conquista. Como eu gosto de sarados, eu tenho que estar sarado pra "ficar"9 $\mathrm{com}$ um cara sarado. Ele não vai "ficar" comigo se eu for gordinho (...) No meio gay é isso que encontramos, ai de você se não tiver bem, vai ser mais difícil, você é excluído, os amigos falam com você meio torto, não te convidam para as festas, não querem que você participe das sociais [reuniões em casa entre amigos]. (Entrevistado A)

Em uma sociedade homossexual, que tem como primeira impressão o corpo antes de tudo, pra você estar dentro do meio é preciso se adequar, se encaixar, é ser cuidado. Eu na verdade nem gosto de caras fortões, mas tem que se cuidar, cuidar do corpo, da alimentação, da mente, entendeu? Ser uma pessoa saudável, não digo ser forte, não precisa chegar a ser sarado... Tem que ter cuidado consigo mesmo. Eu me preocupo com a beleza, é assim, não adianta falar que não, o meio te cobra muito isso. (Entrevistado $\mathrm{H}$ )

Meu corpo é muito importante, tenho que dar mais valor a ele, já fiz muita coisa errada [referindo-se a ter aplicado anabolizantes para ficar sarado], agora preciso cuidar melhor de mim, quero voltar aos poucos a malhar, ter uma alimentação saudável. Pretendo em breve conquistar a boa forma, só que dessa vez da maneira certa. (Entrevistado B)

Meu corpo é tudo pra mim, ainda hoje eu vivo do meu corpo, é um veículo de trabalho, além de salva-vidas eu também sou bailarino clássico [por formação, porque não exerce mais esta atividade]. Ele representa o meu estado de espírito, se estou bem, se estou gordo, sarado (risos)... Estava melhor em dezembro (risos), mais sarado (...) (Entrevistado C)

Subsidiariamente a esta evidência, ficou claro, ao longo da pesquisa, que todos os entrevistados - incluindo os não sarados - sentiam-se oprimidos com relação à busca

9 O verbo ficar é usado como sinônimo de namorar, de ter relacionamento amoroso. 
quase escrava do corpo ideal, perfeito. No discurso de um deles chegou a ser construída a imagem de um fantasma que o assola neste sentido:

Esse fantasma é estar sempre bem, é isso que representa pra mim. Tenho que me cuidar sempre ou vou ser trocado por um mais novo ou mais cuidado. Isso não é só pra namorado, serve também pros amigos como já falei. Entende, somos escravos do corpo, e ai de quem não se cuidar, se já é difícil estar no meio sendo saradinho e bem cuidado, imagina para os gordos e peludos... Se bem que tem gente que gosta, mas são poucos (risos). (Entrevistado A)

No nosso meio a cobrança pelo corpo é muito grande, acho que isso é o que esta me levando a malhar atualmente. Os gays reparam muito isso, sabem quando o outro se cuida. Eu me cuido muito, tenho os meus cremes caros, minhas roupas de marca, meu carro, e isso tudo faz parte de mim, de quem eu sou. Não sei se não fosse gay eu não seria assim, acho que é algo meu, sou vaidoso, gosto de me sentir bem, de estar em lugares bons, ser bem tratado, me vestir bem, enfim, tudo de que os gays gostam de usufruir (risos). (Entrevistado C)

De fato, Hospers e Jansen (2005) mostraram que os homossexuais masculinos são mais propensos do que qualquer outro grupo a experimentar angústia e a internalizar a pressão de seus pares. E que, entre os estressores psicológicos, destaca-se a pressão para se adequar ao padrão de atratividade física ditado pela comunidade gay. Segundo estes autores, essa pressão pode se tornar tão intensa que esses indivíduos concentram grande parte de sua energia na aparência corporal e, consequentemente, colocam em risco as saúdes física e mental - o que esta pesquisa corroborou, conforme o relato do entrevistado B:

Eu tive momentos bem difíceis com a minha estima, de estar gordo [...] Depois veio uma fase que eu acreditava que era mais saudável, de malhação, de culto ao corpo, só que não era nem um pouco saudável, pois tomei muita bomba, muita coisa pra ficar bem externamente, e isso não é nada saudável pro corpo. No princípio tem aquele estereótipo de um corpo lindo e maravilhoso, você na busca de um corpo perfeito e as bombas vão te ajudar a conquistar esse corpo perfeito, até o momento que aquilo começa a te prejudicar, sua saúde, então, assim, no meu caso me prejudicou (...) (Entrevistado B).

Vale notar que parte da idéia de culto ao corpo mostrou guardar relação com o envelhecimento. Isto tangencia o achado de Altaf (2009) de que esta fase da vida para os homossexuais masculinos, relacionada muito mais à perda do vigor físico do que à idade cronológica, se inicia mais cedo do que junto aos heterossexuais. Mesmo assim, há modulações neste modo de pensar, com alguns dos entrevistados tendo demonstrado verdadeiro pavor ao envelhecimento, enquanto outros manifestaram uma maior aceitação: 
Sou novo ainda, mas preciso me preocupar com a aparência e começar a me cuidar desde agora. Já fiz depilação a laser na barba, hoje não preciso mais barbear, uso produtos que minha dermatologista indicou para manter a pele bonita. Me preocupo com a aparência desde muito novo, tenho medo de envelhecer... Não sei como vou lidar com isso, quero chegar aos 40 anos com aparência de 25 (risos). Vai ser difícil, mas me cuido pra isso. (Entrevistado G)

Por outro lado, em vários discursos transpareceu também a percepção de que ter um corpo bonito não obrigatoriamente teria a ver apenas com perfeição ou com o tempo que se está disposto a gastar na busca da musculatura definida. No caso, a beleza estaria relacionada a conjunto que equilibra plasticidade com saúde e com bem-estar. Por outro lado, por mais que possa haver uma postura até certo ponto de rejeição ao culto ao corpo nos moldes de escultura física, a um estereótipo, observa-se que perdura a atratividade imanada do físico. Este último permanece como o grande veículo de atração sexual. E isso mantém a corpolatria do gay, em maior ou em menor intensidade:

Eu sou feliz do jeito que eu sou, com um corpo, a minha estrutura desenvolveu, não me mato mais na academia para ser saradão. Eu sou feliz do jeito que sou, se eu não fosse feliz com o meu corpo, eu estaria em um culto ao corpo absurdo, como em alguns momentos da minha vida eu já estive... Obviamente eu tinha um corpo mais desenhado, mais bonito, mais trabalhado. (Entrevistado B).

Já no que diz respeito especificamente à relação das tatuagens com a corpolatria, nas entrevistas foi evidenciado que uma tatuagem pode ser feita pelo gay com o propósito deliberado de embelezar o corpo, de forma a se alcançar um ideal: a atração sexual na busca de um parceiro. Mesmo quando este desenho é esculpido em um corpo não sarado, ficou evidente sua relação com a corpolatria, traduzida no processo de escolha da figura, de sua representatividade aos olhos de terceiros, e de um prazer pessoal em esculpir algo considerado belo em seu físico:

[referindo-se à segunda tatuagem, no formato de fënix] Decidi fazer um desenho lindo, grande e forte, vi o desenho e me encantei com os traços, achei bonito... Mas não tem uma representação pra mim, como a primeira tatuagem tem. Essa segunda eu fiz por fazer, por achar bonito mesmo, pra deixar meu corpo mais bonito, por gostar de tatuagens. Esse foi o verdadeiro motivo. (Entrevistado F)

No discurso do entrevistado $G$ foi identificado que a tatuagem reforçou a centralidade do corpo quando ele diz que, embora tenha escolhido um mantra que está ligado mais ao espírito do que ao corpo, ele o colocou nas costas para chamar atenção, completando o corpo ideal: bonito, saudável, sarado e tatuado. 
Quando decidi fazer esse mantra pela representatividade e significado pra mim, também pensei em que parte do corpo fazer. Escolhi as costas pra ficar mais bonito, assim, quando tirasse a camiseta, todos perceberiam o desenho. Também conversei com o tatuador que letra usar, queria algo mais forte, sombreado, algo bem feito... Pode perceber que existe a preocupação com a distância de cada letra e se ocuparia as costas todas. (Entrevistado G)

Interessante também foi verificar que, mesmo no caso de a tatuagem ter sido inicialmente usada como recurso reparador (feita para encobrir uma cicatriz que desagradava seu portador), posteriormente ela passou a assumir uma conotação diferente, tendo passado a servir para reforçar a centralidade do corpo do usuário no diaa-dia:

Meu corpo é tudo pra mim, e a tatuagem [figura de pimentas] acrescenta nisso, ela é um destaque para as pessoas observarem mais, pra terem um motivo pra puxar assunto e perceberem como eu sou (...) Dizem que sou quente, que faço "tudo" bem feito (risos)... Não preciso falar nada, apenas concordo, estão certas. Aí vêm os elogios pelo corpo bonito, pelo braço definido, pela barriga sarada. (Entrevistado E)

Passando-se à contribuição da tatuagem na formação do eu estendido, a pesquisa trouxe evidências de que as tatuagens de fato possuem forte representatividade para o self:

[...] a tatuagem é a minha marca. (Entrevistado B)

[...] elas representam a minha vida, meus momentos, as fases da minha vida, elas representam o que eu sou. (Entrevistado A)

(...) Tatuagem é algo muito estético, quando você resolve fazer uma tatuagem ela tem um significado muito importante pra você. Independente de como vou ver sua tatuagem, ela sempre terá um significado pra mim. Tatuagem é uma escolha, você pode optar por fazer desenhos que você vai levar pro resto da sua vida e que terão um sentido muito forte pra você (...) Quando eu fiz eu sabia o que estava fazendo e elas representam minha vida. (Entrevistado F)

Por outro lado, a continuidade do discurso deste último homossexual, assim como o discurso do entrevistado C, remetem a Woodward (200o), quando este ressalta que, se a tatuagem se constitui em uma posse, utilizada na construção de identidade e na extensão do self, ela também apresenta uma característica peculiar: ela não pode ser facilmente descartada. Assim, como a identidade é um processo fluido - e que, por isto, pode ser remodelada durante as fases da vida - o portador de tatuagens que sejam representativas de algo que se esvaneceu no passado se vê obrigado a "reinterpretá-las". Não por acaso, Shelton e Peters (2008) observam que é comum encontrar indivíduos que 
se arrependeram das tatuagens escolhidas por diversos motivos, incluindo o desenho, a qualidade, o fato de representarem nomes de ex-parceiros, e diversos simbolismos associados:

Eu e meu namorado, atualmente ex-namorado, decidimos fazer uma tatuagem pra representar todo aquele sentimento... Estávamos em uma face muito boa, tudo às mil maravilhas, decidimos fazer um ideograma japonês que representa o amor, fizemos o mesmo desenho no mesmo lugar, no pé. Enquanto estávamos juntos essa tatuagem significava uma aliança pra nós. Quando terminamos, essa tatuagem perdeu o significado, tudo aquilo em que eu acreditava estava acabado... Olhava o desenho e não gostava mais dele, quero fazer outra tatuagem para cobrir essa. (Entrevistado F)

Escolhi o gato quando estava em uma fase mais delicada da minha vida, era a época em que dançava mais [o entrevistado é bailarino clássico], o balé muito presente em tudo que fazia. Hoje não danço mais como antes, sou salva-vidas atualmente, acho que a imagem de um gato passou... Foi marcante pra mim, mas hoje não tem todo aquele significado. (Entrevistado $\mathrm{C}$ )

Na esteira desta investigação sobre a relação entre tatuagens e o eu estendido, ficou evidenciado que o papel delas neste aspecto pode até transcender o de uma posse enquanto criação e expressão de uma identidade cultural, multicultural ou pessoal (BELK, I988). No caso, esta transcendência remeteu a um aparente papel subsidiário da tatuagem enquanto manifestação de um desejo de reconhecimento, de aceitação e de admiração por parte de terceiros - sejam estes homo ou heterossexuais. Ou seja, é como se, de marginais, as tatuagens tivessem passado a inclusivas, conforme o demonstram os relatos de dois entrevistados:

Fazer uma tatuagem não é só pra si próprio, a gente faz uma tatuagem pra ser vista. Quando você faz uma tatuagem em um lugar intimo, secreto, ai sim é só pra você e pra quem você realmente quer revelar sua intimidade. Mas as tatuagens em partes do corpo onde são mais notáveis, como braço, costas, braços, pernas (...) é uma forma de me mostrar (...) é tipo um bum! Tô chegando, tô aqui pra ser visto, pra chamar a atenção, é muito isso (risos). É importante que notem a minha chegada, a minha presença... (Entrevistado B)

Me tatuei porque queria representar a espiritualidade na minha pele, mas também quero ser notado, quero que as pessoas notem o desenho, notem a minha presença, e ela faz isso. Tem vez que as pessoas chegam em mim e começam a puxar assunto pela tatuagem, querem saber o que significa, pedem pra ver melhor, daí começa a conversa e quando me dou conta, já estou há horas conversando, não mais sobre a tatuagem em si, mas sobre tudo... É legal pensar que ter uma tatuagem me ajuda tanto pra me apresentar, como pra ser mais notado. (Entrevistado $\mathrm{H}$ )

No ponto da pesquisa em que foram procurados dois tatuadores profissionais, foi questionado se haveria alguma preferência no que tange a desenhos e ou a Revista Administração em Diálogo ISSN 2178-0080 
representações por parte dos clientes identificados como homossexuais masculinos. A opinião obtida foi que o processo de escolha tradicionalmente se dava por nomes de companheiros, ou por desenhos pequenos e delicados. O ponto de vista dos profissionais é que a visão dos gays vem mudando aos poucos. Hoje, eles buscam desenhos maiores mais ornamentados e coloridos, com um novo conceito de beleza (por exemplo, flores, que são coloridas, diferentes, bonitas e muito delicadas), onde se inclui uma maior visibilidade da tatuagem em si, e que não raro simbolizam força (por exemplo, estrelas, que são brilhantes e estão sempre em destaque). Isto transpareceu em vários discursos dos gays entrevistados, sendo mencionado também o contraste da delicadeza do desenho com a agressividade representada pelo corpo musculoso:

Tenho observado como as tatuagens vêm crescendo, as pessoas estão escolhendo desenhos cada vez maiores, alguns fecham as costas, outros o braço todo. Tenho inclusive um amigo que também é gay, e que está terminando um desenho oriental, com dragão, carpa, uma lua, várias estrelas, que vai da canela até as costas. Na verdade é uma encaixe de desenhos muito bem escolhidos, todos muito coloridos e está ficando linda a tatuagem dele. (Entrevistado C)

A tatuagem tem ganhado cada vez mais força [...] tenho visto tatuagens cada vez maiores e em todos os lugares do corpo... Os gays, principalmente, acho que eles querem ousar mais ainda, tanto nos tamanhos como nas cores. Quando fiz a minha pensei nisso, adoro tatuagens coloridas e todos estão usando muito. (Entrevistado A)

A tatuagem caiu no gosto das pessoas mesmo, quase todo mundo tem tatuagem, meus amigos todos têm, acho que um ou outro que ainda não fez... São desenhos deferentes, não sei de onde o povo tira criatividade pra inventar tantas tatuagens bonitas, uma que se junta a outra e vira uma só, tatuagens muito grandes, lindas... (Entrevistado H)

O gato me identifica, ele me cativa, expressa minha personalidade gay, o gato é doce, de fato, quando ele tem que ser felino (risos). (Entrevistado B)

Foi difícil chegar à conclusão de como seria a tatuagem, já que queria algo com traços fortes, porém algo mais fino, nada grosseiro... Tinha que ser um desenho bem feito e muito bem trabalhado... Esse desenho exigiu muito do tatuador, mas o resultado final ficou ótimo, quando as pessoas elogiam significa que está bonito... (Entrevistado G)

Ainda confirmando a informação dos tatuadores, alguns dos gays entrevistados trazem na pele a inscrição do nome do namorado ou suas iniciais, o que se encaixa na observação de Ahuvya (2005) de que as posses amadas podem indexar lembranças de eventos importantes ou de relações ocorridas em alguma fase da vida: 
(...) quando decidimos fazer as tatuagens [a dele com as iniciais do namorado, e a do namorado com as iniciais dele], sabíamos que seria uma marca na pele de uma história de amor, independente se acabaria ou não. Decidimos simbolizar esse sentimento pra sempre, ele significou muita coisa pra mim. (Entrevistado A).

(...) O nome do meu ex-namorado foi o que mais representou pra mim, em uma das vezes que terminamos e quando voltamos pensamos em fazer algo pra representar nossa união, a história que vivemos juntos. Tive a ideia de tatuar o nome dele, e certo dia cheguei em casa com a tatuagem em sua homenagem, ele ficou super feliz, foi algo muito bom. (Entrevistado C)

Já no que diz respeito a preferências quanto a figuras específicas, na pesquisa ficou bem claro que não há símbolos que sejam estereotipados pelos gays:

Todas as minhas tatuagens [ele possui três: gato, mandala e nome do ex-parceiro] são símbolo da minha homossexualidade sim, pois quando estava no curso [de salva-vidas] elas chamavam muito a atenção, pois eu ficava só de sunga no meu treinamento de salva-vidas. (Entrevistado C)

De repente vi uma fênix que me chamou muito atenção e decidi fazer, um desenho lindo, grande e forte, fiz nas costas e é enorme. Mas não teve nada prévio, não pensei no que representa, escolhi ao acaso, vi o desenho e me encantei com os traços. (Entrevistado F)

A escolha do desenho normalmente se traduz em um momento muito especial e pessoal para o tatuado, quando o que é levado em conta é a imagem a ser incorporada ao seu corpo. Além de ser escolhida a partir de critérios plásticos como visto acima - ela tem que ser considerada bonita - também poderá sê-lo a partir de um critério social. Isto porque, num reforço à contribuição da tatuagem na formação do eu estendido, o tatuado acredita que as demais pessoas poderão admirá-lo a partir deste desenho. E este último passa a ser fundamental, central, carregado de simbolismo:

Essa segunda tatuagem [tribal, parecida com uma figura geométrica] eu pensei muito antes de fazer, queria algo diferente, um desenho que fosse feito pra mim. Como eu conheço um tatuador, fui no estúdio e falei o que queria, pensando e desenhando juntos. O cara é muito bom, entendeu na hora o que eu queria, acho que ele já está acostumado com esses pedidos de desenhos exclusivos (risos). Ficou muito bom, é uma mistura de tribal com figura geométrica. Todos que vêem a tatuagem logo perguntam o que significa, parece que a figura se movimenta. (Entrevistado A)

Não tinha um desenho especifico pra fazer. Procurei um tatuador indicado pelo meu amigo, ele me deu várias opções de tatuagens, gostei da pimenta, fomos mexendo, incrementando, colocamos umas folhinhas, uns galhos, tem uma sombra de fundo... Quando vi o desenho pronto não tinha pensado que na pele ficaria tão bem feito e bonito. Adorei o resultado final e a cada dia me identifico mais com o desenho, fui muito feliz na escolha. (Entrevistado E) 
Por outro lado, não é incomum que a escolha da figura se origine de desejos afastados por completo da sexualidade, sejam eles ligados a valores simplesmente familiares ou até mesmo religiosos:

(...) a minha primeira tatuagem é o nome da minha mãe, é uma pessoa que representa muito na minha vida. Antes das tatuagens eu era diferente, não me sentia tão bem como sinto hoje, além de ter o nome da minha mãe na minha pele, ela é uma pessoa muito especial, representa demais pra mim (...) (Entrevistado A).

(...) A terceira [tatuagem tribal] é uma homenagem à família, tem as iniciais de todos os meus sobrinhos, pai, mãe e minha irmã. Essa sim, diferente da segunda eu fiz pra representar a continuidade da minha família. Tive o cuidado de pensar em um desenho e encaixar as iniciais de todos da família, queria representar todos eles na minha pele (Entrevistado F).

(...) e o significado dela [da tatuagem de um mantra] pra mim é compaixão. É um mantra tibetano, escrito em tibetano, que os monges pronunciam mais nas rezas deles. Quer dizer várias outras coisas, mas o principal é compaixão. E embaixo tem um símbolo do om, é um semi-Deus ganesha, o semi-Deus da prosperidade, de quebra de obstáculos. Enfim, o significado dela pra mim é também é um pouco de religiosidade, mas no que eu acredito é mais pelo significado que pela estética. É lógico que eu fiz de uma forma que tivesse uma estética legal, mas o objetivo mesmo é o significado. (Entrevistado G).

(...) quis fazer, por ser uma coisa bonita, por ser uma arte também, eu acho que pra se tatuar tem que ter um significado, fazer um tribal maori ${ }^{\text {\O }}$ com um símbolo $o m^{\mathrm{II}}$, que é um mantra de cura. Mas também é mais por esse lado mesmo, por eu gostar e achar bonito. Ela tem um significado pra mim, e as pessoas acabam percebendo e gostam da tatuagem, ela significa a vida, é o sol do universo. (Entrevistado H)

Interessante notar que, até mesmo quando a escolha do desenho tem um propósito prático, ela pode se dar obedecendo a uma representação. No caso do entrevistado E, as duas pimentas tatuadas para ocultar uma cicatriz indesejada remetiam a homens muito especiais que passaram pela sua vida, embora não necessariamente namorados. E, curiosamente, com o passar do tempo estes desenhos passaram a adquirir outro significado, conforme contribuíram para lhe dar uma imagem considerada sexy:

(...) ela mostra o que eu sou, uma pessoa quente, fogosa, capaz de apimentar qualquer relação... Engraçado isso, né, as pessoas olham as minhas pimentas e dizem na minha cara que seu sou "quente na cama" (risos)... Nunca pensei que aconteceria assim, pensei que não teria esse significado todo para as pessoas, que fossem capazes de ver a tatuagem e fazer um levantamento de como sou. (Entrevistado E)

10 Povo primitivo da Nova Zelândia.

11 Símbolo da meditação indiana.

Revista Administração em Diálogo

ISSN 2178-0080

Programa de Estudos Pós-Graduados em Administração

Pontifícia Universidade Católica de São Paulo 


\section{Conclusões, Limitações e Sugestões de Futuros Estudos}

A pesquisa evidenciou que o uso de tatuagens enquanto expressão da identidade do consumidor homossexual masculino assumido se dá conforme os desenhos são claramente utilizados na projeção das personalidades de seus donos e de seu modo de vida, da representação de eventos que lhe sejam relevantes, e de sentimentos especiais. Por outro lado, esta expressão de identidade nem sempre se mostrou relacionada à sexualidade - na verdade, na seleção de sujeitos realizada, muito poucos destes indicaram haver esta relação. Para alguns dos homens aqui pesquisados, a ligação da tatuagem à homossexualidade é encoberta pela maior importância dada a homenagear o parceiro, que - por acaso - é do mesmo sexo.

Os resultados, portanto, sugerem que, para os consumidores homossexuais masculinos assumidos, a tatuagem de fato é formadora do seu eu estendido. Por outro lado, seu uso como expressão de identidade relacionada à sua sexualidade se dá caso a caso; e, mesmo quando ocorre, esta expressão pode ocorrer de forma secundária, conforme seja eclipsada pelo desejo de se homenagear um homem-parceiro.

Quanto ao aspecto da centralidade do corpo para o homossexual masculino, os oito indivíduos entrevistados concordaram que corpo bonito é a chave para se conseguir um parceiro, com esta busca pela perfeição podendo inclusive induzir à adoção de atitudes nocivas à saúde. Ademais, a corpolatria é vista como uma forma de buscar "enganar" a passagem do tempo, conforme o envelhecimento é uma questão de estresse constante para o homossexual masculino.

Ficou evidente, também, que a tatuagem reforça a centralidade do corpo, conforme ela colabora para obtenção de um corpo mais bonito até mesmo quando representa algo espiritual. Da mesma forma, estes desenhos corporais apareceram como uma autocomplementação simbólica da identidade homossexual masculina, sendo, portanto, parte do eu estendido destes homens. Trata-se de símbolos estampados na pele, cuja grande diferença em relação a bens físicos que são adquiridos para complementar a identidade de seus donos é que não são facilmente descartáveis.

Por seu turno, a escolha de tatuagens por parte dos homossexuais masculinos obedece a um tipo de padrão, que está se alterando atualmente. De acordo com os 
tatuadores, as escolhas teriam passado de nomes de companheiros, ou de desenhos pequenos e delicados, para desenhos maiores, mais ornamentados e coloridos.

Da mesma forma, há particularidades individuais intervenientes no consumo de tatuagens por parte dos homossexuais masculinos, com influência forte, direta e constante, inclusive oscilando conforme seu usuário passa por transformações em seus momentos de vida. Fatores tão diversos como homenagear a família, apresentar conceitos filosóficos ou até chamar a atenção de terceiros estão por trás da decisão de usar tatuagem - muito provavelmente como acontece junto aos heterossexuais reforçando a percepção de que a homossexualidade em si influencia apenas de forma subsidiária nestas escolhas.

É importante ressaltar que os achados desta pesquisa devem ser interpretados à luz de algumas limitações. No caso do método qualitativo apoiado na variante soft da AD tradicional colocada por autores como Vergara (I997), Gaskell (2004) e Gill (2004), ela pode de ressentir de eventuais dificuldades de comunicação com o entrevistado, por exemplo, no que diz respeito à linguagem utilizada pelo entrevistador. A captação das emoções, por parte deste último, durante as conversas também pode ser prejudicada por fatores incontroláveis, assim como a transcrição do discurso do entrevistado pode carecer de total fidedignidade. Por último, sempre permanece a dúvida quanto à total imparcialidade na interpretação dos resultados

Pelo lado das limitações específicas a essa pesquisa, podem-se apontar duas em especial. Uma delas remeteu à ansiedade observada por parte de todos os homossexuais entrevistados em desviar a conversa para assuntos relativos especificamente à homossexualidade. Isto obrigou a uma atenção redobrada para que o foco fosse mantido unicamente na linha dos assuntos pertinentes à investigação. A outra limitação refere-se à dúvida quanto a ser isento de limitações o reconhecimento dos clientes gays por parte dos dois tatuadores entrevistados, tendo em vista que este reconhecimento de limitou a duas formas - a autoidentificação dos clientes ou a apresentação de postura considerada afeminada do ponto de vista puramente pessoal dos tatuadores.

Em que pesem estes elementos, a presente pesquisa contribui academicamente. Por exemplo, ajuda a aumentar o conhecimento sobre o consumidor homossexual masculino no País, subgrupo que não tem recebido maior atenção dos estudiosos, em 
que pese seu peso na sociedade brasileira. Além disto, situa este maior conhecimento no caso específico do consumo de tatuagens, considerando-se que a busca bibliográfica para a composição do referencial teórico não apontou nenhum trabalho a respeito realizado no Brasil na área de comportamento do consumidor, muito menos no que diz respeito a consumidores homossexuais.

Finalmente, como sugestão para estudos futuros sugere-se estratificar este tipo de estudo para homossexuais masculinos de diferentes faixas de idade e de renda, assim como replicá-lo junto a homossexuais femininas.

\section{Referências}

AAKER, A.; KUMAR, V.; DAY, G. S. Pesquisa de marketing. São Paulo: Atlas, 2004.

AHUVIA, A. Beyond the extended self: loved objects and consumers` identity narratives. Journal of Consumer Research, Gainesville, v. 32, p. I7I-I84, 2005.

ALCINA, M. Tattoos as Personal Narrative. Thesis of Master of Arts.New Orleans, 2009.

ALTAF, J. A relação entre o eu estendido do público homossexual masculino e seu consumo de vestuário de luxo. Dissertação de Mestrado (Administração e Desenvolvimento Empresarial), Universidade Estácio de Sá, Rio de Janeiro, 2009.

ALTAF, J.; TROCCOLI, I. Esta roupa é a minha cara: gays, luxo e consumo. Rio de Janeiro: Garamond,2OII, IO7p.

ANJOS, G. Identidade sexual e identidade de gênero: subversões e permanências. Revista Sociologias, ano $2, \mathrm{n}^{\circ} 4, \mathrm{jul} / \mathrm{dez}, \mathrm{p} .274^{-} 3 \mathrm{O} 5,2000$.

BARBOSA, L.; CAMPBELL, C. Cultura, consumo e identidade. Rio de Janeiro: FGV, 204 p., 2007.

BAUDRILLARD, J. O sistema dos objetos. São Paulo: Perspectiva, I973.

BAUDRILLARD, J. A sociedade de consumo. Lisboa: Edições 7o, I981.

BELK, R. Possessions and the extended self. Journal of Consumer Research, Gainesville, v.I5, p.I39I68, I988.

BOURDIEU, P. Distinction: a social critique of the judgement of taste. Cambridge, MA: Harvard University Press, I98I.

CAVALLET-MENGARELLI, A. Interações entre autoconceito e personalidade da marca nas representações de consumo de adolescentes. 2008. I87ff. Dissertação (Mestrado em Administração) Universidade Federal do Paraná. Curitiba, 2008.

CESARE, N. Wearing your life as a sleeve: examining tattooing as a form of postmodern identity expression. Monography. Ohio, $20 \mathrm{OII}$. 
DAMASCENA, E.; FARIAS, S. Os elementos sensoriais em supermercados: um estudo junto a pessoas com deficiência visual na perspectiva da pesquisa transformativa do consumidor. In: XXXVII Encontro da ANPAD. Anais...Rio de Janeiro (RJ), setembro, 2013

DITTMAR, H. Consumer culture, identity and well-being. New York: Psychology Press, 27I p., 2007. DORON, R; PAROT, F. Dicionário de psicologia. São Paulo: Ática, r998.

FOLLETT, J. The consumption of tattoos and tattooing: the body as permanent text. Thesis of doctorate. Wolverhampton: s.n., 2009.

GASKELL, G. (org.). Pesquisa qualitativa com texto, imagem e som: um manual prático. 3. ed. Petrópolis: Vozes, 2004.

GILL, R. Análise de discurso. In: BAUER, Martin W.; GASKELL, George (org.). Pesquisa qualitativa com texto, imagem e som: um manual prático. 3. ed. Petrópolis: Vozes, p. 244-270. 2004.

GOLDENBERG, M. Nu e vestido: dez antropólogos revelam a cultura do corpo carioca. 2 . ed. Rio de Janeiro: Record, p. 9, 2007.

GONTIJO, F. Carioquice ou carioquidade? Ensaio etnográfico das imagens identitárias cariocas. In : Goldenberg, M. (org.), Nu e Vestido: dez antropologos revelam a Cultura do Corpo Carioca- Rio de Janeiro: Record, p. 4I-78, 20O7.

GOULDING, C., FOLLETT, J., SAREN, M.; MACLAREN, P. Process and Meaning in 'Getting a Tattoo'. Advances in Consumer Research, v. 3I, p. 279-284, 2004.

HALL, S. A identidade cultural na pós-modernidade. па ed. Rio de Janeiro: DP\&A, 2006.

HAWKINS, D., MOTHERSBAUGH, D.; BEST, R. Comportamento do consumidor: construindo a estratégia de marketing. Rio de Janeiro: Elsevier / Campus, 508p., 2007.

HOSPERS, H.; JANSEN, A. Why homosexuality is a risk factor for eating disorders in males [Electronic version]. Journal of Social and Clinical Psychology, London, v. 24, n. 8, p. II88-I2OI, 2005 .

HOWARD, J. Social psychology of identities. Annual Review of Sociology, Palo Alto, v. 26, p. 367$393,2000$.

IRIGARAY, H. Estratégia de sobrevivência dos gays no ambiente de trabalho. XXXI Encontro da ANPAD (ENANPAD). Anais... Rio de Janeiro (RJ), setembro, 2007.

KARSAKLIAN, E. Comportamento do consumidor. São Paulo: Atlas, 339 p., 2009.

KATES,S. Out of the closet and out on the street!: gay men and their brand relationships. Psychology \& Marketing, v. I7, p. 493-513, 2000.

LANDOWSKI, E. Presenças do Outro. São Paulo: Perspectiva, I83 p., 2002.

LE BRETON, D. Signes d'identité. Tatouages, piercings et autres marquescorporelles. Paris: Métailié, 2002.

LEITÃO, D. Mudança de significado da tatuagem contemporânea. Cadernos IHU Idéias, n. I6, p. I22,2004 .

LIPOVETSKY, G. O império do efémero. São Paulo: Companhia das Letras, 1989. 
McCRACKEN, G. The long interview. NewburyPark: Sage. Publications, I988.

MEANY-WALEN, K.; DAVIS-GAGE, D. Body dissatisfaction among gay men: a cultural phenomenon. Paper based on a program presented at the American Counseling Association Annual Conference and Exposition, Charlotte, NC., 2009.

MOVIMENTO GAY. Quem éo público GLS. Postado em I5 ago 2007. Disponível em $<$ http://www.ifd.com.br/blog/publicidade-e-propaganda/quem-e-o-publico-gls/>. Acesso em o3 jul 2 OI2.

NUNAN, A. Homossexualidade: do preconceito aos padrões de consumo. Rio de Janeiro, RJ: Caravansarai, 2003, 36op.

PEREIRA, S. Da "invenção" da homossexualidade ao discurso das posses: uma análise interpretativa da identidade homossexual. Tese de Doutorado (Administração de Empresas) - Fundação Getulio Vargas, Escola Brasileira de Administração Pública e Empresarial, Rio de Janeiro, 2009.

PEREIRA, S.; AYROSA, E. Estigma, Consumo e Identidade de Gênero entre Gays. IV Encontro de Marketing da ANPAD (EMA). Anais...Florianópolis (SC), maio, 2010.

PEREIRA, S.; AYROSA, E. Corpos consumidos: cultura de consumo gay carioca. Revista O\&S, v.I9, n.6I, p. 295-3I3, 2 OI2.

PEREIRA, S.; AYROSA, E.; OJIMA, S. Consumo gay: compreendendo a construção da identidade homossexual através do consumo. Cadernos EBAPE.BR, Rio de Janeiro, v. o, n. 2, 2006.

PERES, M. Corpos em obras: um olhar sobre as práticas corporais em Brasília. Tese de Doutorado (Sociologia) - Universidade de Brasília, Faculdade de Sociologia, Brasília, 2005.

PHILLIPS, C. How do consumers express their identity through the choice of products that they buy? Disponível em: http://www.bath.ac.uk/management/research/pdf/2OO3-I7.pdf. Acesso em 2r jan. $2 \mathrm{OI2}$.

ROCHA, E. Oque é etnocentrismo. São Paulo: Brasiliense, I984.

ROCHA, E. Sociedade do sonho: comunicação, cultura e consumo. Rio de Janeiro: Mauad, 1995.

RUDD, N. Appearance and self-presentation research in gay consumer cultures: issues and impact. Journal of Homosexuality, v. 3, n.I-2, 1996.

SABINO, C.; LUZ, M. Tatuagem, gênero e lógica da diferença. Revista de Saúde Coletiva, Rio de Janeiro, v. I6, p. 25 $5^{\mathrm{I}-27^{2}, 2006 .}$

SCHIFFMAN, L.; KANUK, L. Comportamento do consumidor. Rio de Janeiro:LTC, 475 p., 2000.

SCHOUTEN, J. Selves in Transition: Symbolic Consumption in Personal Rites of Passage and Identity Reconstruction, Journal of Consumer Research, Gainesville, v. I7, p. 4I2-425, I99I.

SHELTON, J.; PETERS, C. An Exploratory Investigation of Identity Negotiation and Tattoo Removal.Academy of Marketing Science Review, v. I2. p. I-I3, 2008.

SLATER, D. Cultura do consumo \& modernidade. São Paulo: Nobel, 2I6p., 2002.

SOLOMON, M. O comportamento do consumidor. Comprando, possuindo, sendo. São Paulo: Bookman, 680 p., 2 OII. 
TEBAR, D.; ROSSETTI, F. Homossexualidade, consumo, cidadania e hospitalidade. Caderno Virtualde Turismo, vol. 4, n. 2, pp. 9-I6, 2004.

THIRY-CHERQUES, H. Saturação em pesquisa qualitativa: estimativa empírica de dimensionamento. Revista PMKT, ed. o3, outubro, pp. 20-27, 2009.

TRINCA, T. O corpo-imagem na "cultura do consumo": uma análise histórico-social sobre a supremacia da aparéncia no capitalismo avançado. Dissertação de Mestrado (Ciências Sociais), Universidade Estadual Paulista, Marília, 2008.

TSUJI, F.; PEREZ, G.; PENNA, G.; CAITANO, I.; SILVA JUNIOR, V.; CORTES, V.; TARQUINI, J. Revista Be - Apostando em um Novo Mercado. XXX Congresso Brasileiro de Ciéncias da Comunicação, Santos, 2007. Disponível em $<$ http://www.portcom.intercom.org.br/expocom/expocomnacional/index.php/PEC$\mathrm{NAC} /$ article/view/ $7^{2} / \mathrm{I}_{2} 3^{>}$. Acesso em o8 fev. 2012.

TUCKER, P.;MONEY, J. Os papéis sexuais. São Paulo:Brasiliense, 200 p., I975.

TWITCHELL, J. In defense of materialism. Across the board, vol. 37, issue 3, march, 2000.

VALENTE, M. L. C. Fatores importantes para a escolha do telefone celular pelo consumidor adolescente. 2006. I4I f. Dissertação (Mestrado Administração) - IBMEC, Rio de Janeiro, 2006.

VEBLEN, T. A Teoria da Classe Ociosa. New York: MacMillan, I899.

VELIQUETTE, A.; MURRAY, J.; CREYER, E. The tattoo renaissance:an ethnographic account of symbolic consumer behavior. Advances in Consumer Research, v.II, p.43-59, $199^{8}$.

VELIQUETTE, A.; MURRAY, J.; EVERS, D. Inscribing the personal myth: The role of tattoos in identification. Research in Consumer Behavior, London, v. IO, p. 35-7O, 2006.

VERGARA, S. Projetos e relatórios de pesquisa em administração. São Paulo: Atlas, 2007, IO2p.

WARLOP, L.; BECKMANN, S. Special session summary the re-emergence of the body in consumer behaviour research. European Advances in Consumer Research, v. 5, p. I8-22, $200 \mathrm{O}$.

WATTANASUWAN, K. The self and symbolic consumption. The Journal of American Academy of Business, Cambridge, v. 6, n. I, p.I79-183, 2005.

WOODWARD, K. Identidade e diferença: uma introdução teórica e conceitual. In: Silva, Tomaz Tadeu da (org.). Identidade e diferença: a perspectiva dos estudos culturais. Petrópolis: Ed. Vozes, p. $7-72,2000$. 